\title{
The Constitutionalization of Local Government in Developing Countries-Analysis of African Experiences in Global Perspective
}

\section{Dele Olowu}

Africa-Europe Foundation, The Hague, Netherlands.

Email: dolowu2@yahoo.com; africaeuropefoundation@gmail.com

Received April 22 ${ }^{\text {nd }}, 2012$; revised May 20 ${ }^{\text {th }}, 2012$; accepted May 28 ${ }^{\text {th }}, 2012$

\begin{abstract}
The constitutionalization of local government is a distinctive contribution of developing countries to governance reform and the policy and practice of modern public administration. Local governments in most western and industrialized societies are creatures of the national government and are essentially statutory bodies-created, modified and suspended or eliminated at will by the state statutes. In fact, in the Anglo Saxon tradition, these institutions are referred to as local authorities and never local government. In seeking to enhance the capacity of sub-national entities against overbearing central authorities countries as disparate as Brazil, India, Philippines, Bolivia, Colombia, South Korea to mention only a few constitutionalized their local governments. This boosted the status and role of these entities in terms of the policy processes for local level development, services delivery and citizen participation. There have also been a number of challenges-local elite capture or corruption, capacity, coordination, equity and stability issues. However, a consistent overall consequence when properly implemented has been a positive impact on service delivery and the enhancement of the interface between local government and local governance as well as the strengthening of intergovernmental relations. A number of African countries have followed this global good governance practice but the results have been mixed. This paper reviews the experiences of Nigeria, South Africa, Uganda and Ghana that have all constitutionalized local governments and seek to explain the differential outcomes in each country context. This is an important issue as a number of other countries that have recently initiated fundamental governance changes have incorporated local government reform as a part of the constitutional reform process. These countries include Kenya while a number of other countries in eastern, southern and especially northern parts of the continent are likely to follow this example as they engage the constitutional reform process.
\end{abstract}

Keywords: Costitutionalization; Local Government; Africa

\section{Introduction}

Most African countries built their political systems on the traditions they received from their colonial masters. These structures have remained intact several years even after political Independence for various reasons. One area that has changed radically is in respect of the constitutionalization of local authorities.

According to the received tradition, local authorities are creatures of the national statute. If it wills, the state can modify, regulate or totally erase its creature, the local authority. Many developing countries have however departed from this tradition for a variety of reasons that we shall examine in this paper. We shall also assess whether this policy innovation has delivered on expectations of the policy makers in these countries.

We start with a discussion of the received tradition and then the reasons why countries departed from this tradi- tion. The experiences of different countries are reviewed and a conclusion is then made.

\section{Patterns of Local Government in Developed Countries}

The governance of local communities has attracted renewed interest in recent years for a variety of reasonspolitical, social and economic. Both the World Bank and the United Nations Development Program (UNDP) have devoted considerable attention to the subject as a part of their development promotion mandate [1-3]. Of the different patterns of local government, three have been particularly dominant, helped as they were by colonial adventures. These are the continental tradition, the AngloSaxon and the socialist patterns (Table 1). There are variants of these basic patterns, resulting in several possible combinations of the basic three [4]. 
Table 1. Patterns of local government.

\begin{tabular}{|c|c|c|c|}
\hline & Responsibilities & Financial Resources & Legal Status \\
\hline Anglo-Saxon & $\begin{array}{l}\text { Property-related-wide, Human ser- } \\
\text { vices-narrow; } \\
\text { mainly social services; }\end{array}$ & $\begin{array}{c}\text { Narrow_- property tax related/few } \\
\text { state grants }\end{array}$ & $\begin{array}{l}\text { Dillon's rule/Ultra vires } \\
\text { Local authority creature of state }\end{array}$ \\
\hline Continental & $\begin{array}{l}\text { Property-related-wide } \\
\text { Human services-medium }\end{array}$ & $\begin{array}{l}\text { Property and income revenues-wide } \\
\text { State transfers-wide }\end{array}$ & $\begin{array}{l}\text { Local authority small and dependent on } \\
\text { national }\end{array}$ \\
\hline Socialist & $\begin{array}{l}\text { Property-related-wide, } \\
\text { Human \& Economic services-wide }\end{array}$ & $\begin{array}{l}\text { Broad-but tied to the state: transfers } \\
\text { from local to national }\end{array}$ & $\begin{array}{c}\text { Complete subordination of local } \\
\text { authority to national body_-although } \\
\text { separate structures exist }\end{array}$ \\
\hline
\end{tabular}

In essence, these different forms treat local governments as creatures of the national government and are not a part of the national constitution. In federal systems, local governments are incorporated in the state constitutions or created by national or state legislatures or are based on executive pronouncements as in China. In the United States, local governments are governed by what the judiciary has referred to as the "Dillon's rule", by which local authorities can only carry out what has been specifically assigned to them by the state legislature. This is their own variant of the doctrine of ultra vires, inherited from the British tradition, that requires local authorities to stay within the confines established by strict legal provisions of the national/state government. Nevertheless, local authorities have access to specified-though limited-responsibilities and financial and human resources.

Generally, the continental pattern provides for much clearer subjugation of semi-autonomous local authorities to the national government through financial and administrative arrangements. They are wholly dependent on the state for their responsibilities and financial resources, even for revenues they collect. In addition, local authorities are governed by state personnel through either the full or partial prefect who coordinates the work of all agencies of the government at the local level. Essentially, there exists no separation between central and local authority administrative personnel and even national political officials serve as representatives at the local level just as the local authority elected representatives also serve at national levels.

The socialist model, represented most strongly by the Chinese model is at once the most integrated into the national system but also the most comprehensive in terms of its provisions of local government responsibilities. For all practical purposes, local governments in this system are part and parcel of "the government" and are responsible for a wide range of economic and social services. These local governments are the local expression of the national government and in fact collect revenues on behalf of all other levels.

Generally, patterns in which local autonomy are emphasised also constrain the areas of competence of local authorities into property related services-e.g. town planning, roads, water, etc, but limited human serviceseducation, health and water and sanitation, etc.

The financing of local authorities is also heavily dependent on national authority transfers and property taxes. Those countries that treat local authorities as delegated organs grant them more responsibilities (both propertyrelated, human services-related and even economic and security concerns) but also provide them with extensive resource bases-e.g. own income based resources besides the property taxes, etc. This is the pattern found in China and strong social welfare states like those in Scandinavian countries.

None of these systems however constitutionalizes local authorities. The only country that has had local government constitutions for a long time before relatively recent times is Switzerland.

In spite of these variations, one is struck by the fact that a review of governance structures in industrialized countries shows two remarkable features. The first is the tendency for comparative strength of local authorities when compared to national and governmental expenditures and employees' size, reflecting their huge responsebility for a wide range of social and economic services (Table 2). The second phenomena is the convergence of the various systems - this has been further helped by regionalization, especially the European Union, with a clear sense of administrative space, a practice that is followed by other nations in recent times. These two points underscore the significance of local authority as the first and primary level of governance, and one that serves both as a form of community self-government and agent of the national state. It is indeed a fail safe mechanism in that it ensures that the basic services are delivered irespective of the color or quality of the government in power at the national level at any point in time. In a way these basic governance institutions provide the basic infrastructures for development, the very thing that seems to hold back several developing countries.

\section{Patterns of Local Government in Developing Countries}

Unfortunately, local authority systems in developing 
Table 2. Local government as \% of total government employees, 2000-World \& Africa.

\begin{tabular}{cccc}
\hline Australia & 88.8 & RSA & 44.4 \\
Germany & 88.5 & Nigeria & 30 \\
USA & 86.5 & Botswana & 27 \\
Canada & 86.9 & Ghana & 25 \\
Sweden & 82.7 & Uganda & 10 \\
Belgium & 65.6 & Morocco & 4.6 \\
UK & 52.4 & Tunisia & 2.0 \\
France & 48.4 & Senegal & 0.6 \\
Netherlands & 25.8 & Cote d'Ivoire & 0.29 \\
& & Benin & 0.12 \\
China & 93.3 & & \\
Chile & 34.3 & & \\
Malaysia & 31.8 & \\
Indonesia & 29.4 & & \\
Bolivia & 11.3 & & \\
\hline
\end{tabular}

Source: Kersting, et al. 2009.

countries combined the worst elements of these systems, partly because their development was closely connected to colonial history and the excessive centralist orientation of the first set of post-independence leaders. They lacked responsibilities, resources and were completely subordinated by law to the national government. It was easy for state politicians to manipulate local authorities and keep them weak so they could enjoy the priviledges of absolute control rather tan limited government. Reforms that were tagged decentralization within this framework only provided much needed opportunity to further weaken local authorities and in a few cases to permanently suspend them—as in Tanzania under the Mwalimu (Nyerere) in the 1970s as a part of the program of ujaamization.

Over time some developing countries began to realize that their political and economic problems might not be unconnected with the disarticulation from the rest of the society and began to review their approaches to development and governance with decentralist lenses.

Decentralization became an important element of governance and public sector reforms. One close observer noted that $40 \%$ of all public sector reforms in developing countries in the period between 1980 to 1999 included decentralization and local government [5]. New reform governance elements surfaced. One of the most important innovations has been the constitutionalization of local government, a peculiar response from developing countries. As a part of what has been described as the "third wave of democratic reform" that swept the world in the 1970s on, local authorities were given constitutional status-this meant that state legislatures could not easily suspend them and their responsibilities and resources at will as they used to do. It also meant that they become important players in economic and political development as they controlled substantial national resources and expenditure heads. With more responsibilities and resources, they attracted more significant political and administrative players in their respective communities. Effectively, in some of these countries the state was being decentralized. In some cases, the constitutionalization came as a result of struggle from below-as in several Latin American countries: Colombia, Bolivia while in others it was as a result of elite compromises from the top-Brazil, India, Philippines, etc. Constitutionalization became an important element of decentralization and local government reforms in developing countries.

Several African countries began to take interest in these developments as they embarked on governance and wider constitutional reforms. Nigeria was the first African country to embark on such a reform program as a part of the effort of the military to return to barracks and return the country to civilian governance. Local government was seen by them as a sure way to rebuild democracy that had been undermined by post-independence developments that had done havoc to the body politic. It was also an opportunity, according to these rulers, to ensure that the new found oil wealth would be well distributed through improved basic infrastructures [6]. Other countries like Ghana, Republic of South Africa and Uganda followed suit. We shall review these experiences in the coming paragraphs.

\section{Arguments for Constitutionalization}

There are several arguments for constitutionalization. Some of these are reviewed in this section while much later on the arguments against and the challenges of constitutionalization would be examined.

\subsection{Socio-Economic Development}

Development has become more comprehensive in concept and practice and great stress is laid on sustainability of development. The strongest case for constitutionalization is that it empowers communities to be able to cooperate as independent actors in relating to the huge impulses for change from the national organs of governance. The absence of these grassroots institutions has not allowed developing societies to integrate development 
planning and implementation. It has also not given sufficient weight to the basic infrastructure challenges confronting many societies that are quite basic-rural roads, community health, elementary schools and rural water supply and sanitation. Moreover, these local institutions can also work with the variety of other governance actors in the community to improve on governance and development outcomes.

However, the institutions that can engage and impact on development outcomes must have certain basic elements which are all promoted by constitutionalization.

These elements include the following:

- Clearly defined boundaries: The boundaries of the service area and the individuals or households with rights to use the services are clearly defined;

- Proportional equivalence between benefits and costs: Rules specifying benefits must balance costs or inputs by the various service users;

- Collective choice arrangements: Individuals affected by operational rules must be able to modify these rules;

- Monitoring - the users of the services provided by the local authority must be able to monitor or audit the production of the services;

- Graduated Sanctions: Users who violate operational rules are likely to receive graduated sanctions-depending on the seriousness of the offence;

- Conflict Resolution Mechanisms-low cost conflict resolution mechanisms must exist;

- Minimal recognition of rights to organize and devise own institutions and modifications not challenged by external governmental agencies;

- Nested Enterprises - exist for multiple layers of enterprises responsable for differing functions specified above: appropriation, provision, monitoring, enforcement, conflict resolution and governance activities [7].

For these reasons constitutional decentralization underscores the transfer of four key elements from central to local operators-responsibility, authority, resources and accountability arrangements [8].

\subsection{Responsiveness, Transparency and Accountability}

A major challenge of governance in developing socieities is the tendency for opaque management of resources. The constitutionalization of local government is expected to promote transparency and accountability of governments at the local level as they could no longer pass the buck concerning the development of peoples at the grassroots. Proximity is expected to promote ease of the citizens demanding accountable performance. All of these promote responsiveness.

\subsection{Participation}

By raising the profile and calibre of people who participate in local government, the quality of participation is revitalized in community governance. There is also a stream of new political actors who are having their teeth cut for them at the local level. Constitutionalization not only creates formal structures of participation for citizens it can also encourage informal structures of participation as we shall see when we review the international evidence below.

Of course constitutionalization also has its challenges but these we shall examine much later in this article. We now proceed to review contemporary international experiences before focusing more sharply on the African cases.

\section{Analysis of International Experience}

Brazil was one of the countries to go for the constitutionalization of local governments in the developing world. Local authorities in that country had been used by politicians as a political pun and in fact presidents used to appoint the mayors of the cities and states, as in most Latin American countries. In 1946 Brazil undertook a major reform of her local government system which had some key elements. It defined a municipality, municipio in Portuguese or (local government) in terms of population and area size. It assigned them with responsibilities and autonomous financial and human resources and codified all of these in the constitution. Finally, local governments were accorded a third tier status, to complement federal and state governments. Several other countries followed this lead many years later. In October 1988, Brazil further deepened her commitment to constitutional decentralization when the constituent assembly drafted and passed a new constitution that granted more robust autonomy to states and municipalities (local governments). This became the basis for redemocratization after 20 years of military rule. Article 18 of this constitution designated municipal government as the third tier of government of the Brazilian federation and share the same status as state governments. These municipalities enjoy autonomy in terms of their elite recruitment - they hold direct elections for the municipal mayor as well as the council. Moreover, they enjoy broad autonomy in levying taxes nd other forms of incomes, approving expenditures and hiring employees and even contracting debts. Total revenue for municipal governments was $7.4 \%$ of GDP and expenditures was 15\% of total national expenditures in 2004 because they are also beneficiaries of substantial transfers from national and state governments. Since most of these monies are spent on primary or basic education (24\%) and health (22\%), general public ser- 
vices (19\%) and urban and community services (12\%) the impact on service delivery has been considerable. This has also stimulated participation of the masses of the citizens although the constitution also made deliberate provision for greater citizenship participation through community councils and participatory budgeting.

Other countries have also undertaken some form of constitutionalization of their municipal level government but none has been as comprehensive nor impactive as the Brazilian case. For instance, in another Latin American country, Chile, local governments were recognized in the national constitution and were assigned specific functions and finance but they are still subject to the governor's (or state's) discretion. Similarly, in another Latin American federation, Argentina, a new constitution of 1994 established municipal autonomy but on the terms of the provincial constitutions. Local autonomy is not as complete as it is in Brazil in any of these two countries mentioned. Similarly, farther away on the Asian continent, India undertook a major reform of its local government in 1992 with the passage of the 74th amendment to the constitution. This amendment gave local governments constitutional recognition they had been denied for many years and basically codified local government strucutes, financing and composition. While this protected the institution it failed to give it clear-cut responsibilities and tax domain [4]. The experiences of many other developing countries is that these domains are encroached upon by intermiedate bodies which is why con-situtionalization is sought in the first instance.

\section{African Experiences of Constitutionalization}

Nigeria, one of Africa's only two federations (the other is Ethiopia) and containing a diversified population and cultures, was one of the first few countries in Africa to undertake the constitutionalization of her local governments. In many ways, the Nigerian experience runs so close to the Brazilian experience-local governments were used as the instrument for driving redemocratization and the reforms articulated in the 1976 reforms were incorporated into the post-military constitution of 1979 and has been a constant feature of other constitutions (notably those of 1992 and 1999).

The Nigerian constitution gave elaborate recognition to local governments in the national constitution, designnated their exclusive and concurrent functions and empowered them to have own personnel, albeit through local government service commissions that were controlled by the state authorities. The premise of the Nigerian reform were important. State governments had whittled the power and resources of local governments and it is im- portant to restructure and empower so they can be the basic institutions of democracy and also of development. Elections are organized to these bodies by State election bodies. States are also expected, like the national government to make fiscal transfers to local governments even though the latter were assigned specific tax sources as well.

Uganda's corrective government that fought a guerrila war against the predecessor government which it won in 1992 saw devolution as a critical aspect of its development and democratization agenda. To this end, it passed a new constitution in 1995. This constitution enshrined local government as an active agent of democratization and development. A local government act of 1997 futher clarified the powers of local government. The democratic legitimacy of local governments and accountability of local governments have been upheld as councils and council chairpersons are directly elected through a competitive (though non-partisan) system. There is a minimum quota for women, youth and those with disabilities. Local governments' responsibilities are clearly articulated as are the tax handles although they have become increasingly dependent on discretionary grants from the national government. Local governments have control over their personnel-through their district staff councils-although some re-centralization of these personnel and financial powers have occured in recent years $[9,10]$.

Republic of South Africa: In moving from an a racially defined local government system, South Africa went through three major phases which hung around the detailed provisions on local government in the constituton of 1994. The South African constitution of 1997 took this further by dedicating considerable attention to local government. First, the constitution recognises and articulates three spheres of institutional action, thus rendering national, provincial and local governments as equal, separate and autonomous though within the framework of a unitary arrangement. Second, relationship is cooperative not hierarchical and thirdly it establishes the principle of subsidiarity. In addition to the functions of local government-involving public infrastructures-streets, refuse and Street lights - and those requiring user fees such as electricity, water and sanitation-national and provincial governments were to transfer functions and revenues to local governments. Local governments have access to revenues and also manage their own personnel. It is significant that like in Brazil and Nigeria-two countries with extensive decentralist constitutions-fiscal flows from the South African national government does not go through the provincial governments.

In addition, the South African constitution empowers organized local government bodies. For instance, it recongnises the South African Local Government Associa- 
tion (SALGA) and their provincial representatives are nominated to the National Council of Provinces in the national parliament. SALGA also can nominate 2 members of the Financial and Fiscal Commission which advises the ministry of Finance on Budget issues. There are also a number of intergovernmental for that help to facilitate intergovernmental relations. Most of these are located in the President's office.

In Ghana, the 1992 constitution simply incorporated all the key elements of the Military President Rawlings' PNDC Law 207 of 1988. It transferred authority, functions and finance to the newly created district authorities and sub-district structures. A separate system of fiscal decentralization was also articulated that assigned some tax resources to local authorities as well as a consolidated district assembly account and even established the percentage of the national account (not less than 5\%). This constitution stipulated that: "Parliament shall enact laws and take steps necessary for further decentralization of the administrative functions and projects of the central government but shall not exercise any control over the Das that is incompatible with their decentralized status." While DAs have become important players in the national life, the laws have been structured in such a way to ensure that these decentralized institutions operate more as appendages of the national government rather than agents of local economic development. A number of statutory enactments have been made to effectively nullify the broad constitutional mandate. They include the appointment (not election) of the executive heads of the DA, the continuing control of senior staff by the national government, leading to mass sackings of local government staff when the national government changed hands from the ruling party to the opposition. Finally, administrative and fiscal instruments that are controlled by the national government have been effectively utilized to undermine the autonomy granted to the DA. For instance, although the constitution stipulated that $5 \%$ of national revenue must be assigned to local governments, only 3\% - 4\% was transferred between 1994 and 2000. In 2000, when the opposition party was voted into office, it promised to increase the transfers from $5 \%$ to $7.5 \%$. This promise has not been kept six years later [11].

\section{Impact of the Reforms-Services Delivery, Responsiveness and Participation}

A review of experience shows that much depends on how constitutionalization of local government is implemented by political and administrative officials. In federations, when constitutional provisions are implemented nationally, the impact has been quite impressive. When the implementation is carried out at state levels (as in Chile or India) or by administrative officials' resistant to devo- lution (as in Ghana) the results have been minimal.

Table 3 shows the impact of these reforms in terms of the role of local governments in the national economy and services delivery. There are five main attributes of local governments in countries that have pursued codification or constitutionalization. These are firstly, strong constitutional and political status; secondly, higher importance in the economy and services delivery. In fact in the case of Brazil in recent years, the municipal reforms gave strong support to President Lula's program of social compact with impressive results in terms of social indicators. Thirdly, local governments become independent actors in the intergovernmental relations scene. As we saw in RSA but to a limited extent in Uganda, even in unitary countries, local governments are treated not as appendages of the state or national government but as autonomous and key actors in the intergovernmental scene. Fourthly, local governments constitutionalization reform also lead to reforms in citizen participation and governmental responsiveness. In many cases, there has been a different approach to services delivery and management as non-governmental organizations are involved more directly in producing services on behalf of local governments as providers. Finally, there is a stronger culture of contracts and cooperation between the different levels of government and other institutional actorswhat has led many observers to refer to this as a boosting for local governance and not just local government.

Even in Ghana, constitutionalization boosted citizen participation but as the central government controls increased this interest was not sustained either at the local level, which remained non-partisan as in Uganda, and also in other informal community based activities. Nevertheless, these new formal channels of communication are compromised by the large number of nominated members - chiefs, national assembly members etc.

Table 3. Size of local government in national expenditure and gross domestic product, 2004/6.

\begin{tabular}{ccc}
\hline Country & $\begin{array}{c}\text { LG as \% of Nat } \\
\text { Expenditure }\end{array}$ & $\begin{array}{c}\text { LG exp as \% of } \\
\text { GDP }\end{array}$ \\
\hline Brazil & 20 & 6.7 \\
RSA & 29 & 6.1 \\
Uganda & 28 & 5.8 \\
Nigeria & 12 & 5 \\
Chile & 13.2 & 4 \\
India & 4 & 0.8 \\
Ghana & 8 & 3 \\
\hline
\end{tabular}

Sources: Shah 2006, Olowu \& Wunsch 2004, Kersting, et al. 2009. 


\section{Challenges-Global and African}

Constitutionalization confronts challenges in all countries that embarked on it. The most serious among these are the following:

- Adjustment difficulties: Once the terms of the constitution are agreed, change that is ocassioned by social dynamics over time are difficult to effect without going through constitutional amendments. Even modest changes are costly to effect.

- There are also the traditional arguments against devolution. They include capacity issues, elite capture and most importantly coordination issues between the variety of institutional actors within the same nation space. The most serious manifestation of the latter is in respect of stabilization.

- Two other issues have also dogged successful constitutionalization. The first are equity issues - that much thought and expertise is required to ensure that vertical and horizontal equity issues are balanced and not allowed to lead to strong resistance of especially poorly endowed parts of the country. The second challenge is tackling debts by sub-national entities and stabilizing the economy. The experiences of countries that have undertaken constitutionalization shows that this problem would be dealt with through effective intergovernmental mechanisms such as the Brazilian Fiscal Responsibility Law of 2000 which set a general framework for budgetary planning, execution and reporting by all three tiers of government. The law makes provision for constraining public indebtedness and sustaining public finance structural adjustment. It does this with three types of rules-general targets and limits for selected fiscal indicators; corrective institutional mechanisms in case of non-compliance and institutional sanctions for non-compliance. The scope covered includes not only finance but also outlays on personnel by all levels of government.

Countries that go for constitutionalization have demonstrated considerable expertise in tackling the abovementioned challenges with highly sophisticated mechanisms to cope with them. For instance, all the successful cases-Brazil, RSA have sophisticated fiscal mechanisms and participatory mechanisms. The Brazilian participatory budgets have acquired considerable international attention but much less is known about that country's Fiscal Responsibility Law of 2000, mentioned above. This placed strict limits on local (and state) government fiscal debt, regulating it as a ratio of available funds. Similarly, personnel outlays cannot exceed $60 \%$ of net municipal revenues. Act which was used to rein in local (and state) governments' reckless indebtedness and carelessness in handling finance and personnel matters.

By contrast, for many sub-saharan African (SSA) coun- tries these challenges have led to recentralization and de facto-reassertion of central controls-as has been the case in Ghana and Uganda. The Nigerian case is given more attention because compared to others, it is the one country that seems to have done the most to institutionalise local governments through constitutional action. It is also one of the earliest examples of constitutionalization in Africa but which has not been able to achieve some of the benefits associated with this governance improvement strategy. What went wrong?

The principles of devolutionary decentralization were articulated and introduced as a common system and structure of local government in 1976. These reformsincluding the transfer of clearly articulated responsibilities, own resources, huge transfers of oil-based central government transfers to local governments (that grew rapidly from $3 \%$ to $20 \%$ of total national revenues), human resources and accountability structures with local government wide elections for local government chairs and council members-were incorporated into the 1979 and other subsequent constitutions since that time. While all administrations have committed to the rhetoric of these principles, since the return to the civilian democracy in 1999, state governments have been able to fully re-assert their independence of the Nigerian federal government and imposed draconian controls on the local government system. A two-tier federation of the federal and state government seems to have replaced the three -tier federation. State powers have grown compared to local and federal powers, almost returning to the statusquo before the reforms of 1976 started. Many fear that if the present trends continue the pre-1976 situation would fully return together with the abuses of the local government by the state governments.

Salient facts in the Nigerian federal system have further aggravated matters and they include:

1) The lopsided financing of the local government system: All governments are dependent on oil rents but it is particularly aggravating for a system of local government because it does not help the development of a tradition of fiduciary contract between citizens and the local government and consequently of democracy, whether in terms of responsiveness, representativeness or accountability. Furthermore, this excessive dependence on transfers has facilitated the imposition of state controls on local governments as the State Joint Local Governments Accounts Committee (SJLGAC) is chaired and dominated by state officials.

2) Weak Capacities of the Federal Government to protect local governments and the three-tier federation principle. The federal government seems to lack the capacity to influence the state governments to cooperate on local government matters or even to get the national assembly 
to make laws that would enable it to ensure that funds sent from the federation account are judiciously used by all segments of government.

Excessive Powers of the State Government: In the face of weakened federal and local governments, state governments emerge in the Nigerian federal system as very powerful and relatively well-resourced. Unfortunately, these powers do not translate into capacity to better manage the intergovernmental relations between state and local governments in a way that would enable the latter to exercise their autonomy. Rather, the states have sought and got direct controls of the local governments through resources and via their controls over party machinery levers. This is an important point in that if the states were willing they possess the ability to help to build and sustain an accountable system of local government. For instance 25 LGAs in Delta state (south west) received a net allocation of only Naira 1.520 billion or slightly more than one half $(54 \%)$ out of a gross allocation of Naira 2.810billion in the month of June 2010.

4) Party System and Nigerian Democracy: Matters would have been much better if internal democracy existed within Nigerian parties, if the parties focused ideologies that link them to programs and if elections were actually fought and won on the basis of performance. While performance of incumbents does influence party nominations, the key considerations are ascriptive not merit. For instance, a person's state or local government of origin counts much more than performance so is the existence or quality of one's "godfathers", or political sponsors. These challenges become particularly critical because elections, before the massive changes leading to the last national elections in 2011, were won and lost not through the ballot box (which are flagrantly rigged by incumbents) but through party nominations. This might explain why virtually all LG elective positions are filled by the ruling party in most states.

5) Weak Citizen Accountability by LGAs. Even though LGAs are beholden to SGs and are fully accountable, if not dependent on them, none of these translates to effecttive citizen accountability and responsiveness. Most chairpersons of local government lament their helplessness in delivering on the promises they had made to the electorate given the structure of incentives they confronted when they got into office at the party and state government levels [12].

The Nigerian case is sadly not peculiar. The progress of decentralization as we saw in Ghana and Uganda has been seriously eroded in recent years in spite of constitutionalization. It is far worse in other countries that did not have this insulation for the local government system. In Kenya and Tanzania, the central government has replaced the local governments with non-eleted commissioners, a practice that was rife before democratic decen- tralization reforms. Even now, only 18 of the 27 countries on which data exists have powers set their local tax rates, only 12 have borrowing powers and only 9 can pick their own contractors-and all of these only with central government approval. And these in countries that have devolutionary decentralization policies.

\section{Conclusions}

When the RSA case is held in contrast to the Nigerian case, it is clear that much depends on the quality of the implementation and the commitment of the political leaders and the wider political community to the constitutional principles. We also see this difference when we compare the differing international experiences analysed in this paper-e.g. Brazil compared with Chile or India.

First, we may conclude that decentralization is indeed truly political. Where the pressures for decentralization comes from pressures from the people (from below) - as in RSA and the Latin American cases, the process was likely to be sustained. By contrast, where devolution is a largesse given by central governments to either appease donors who play dominant role in the policy and financing processes or deflect nascent pressures to democracy - as in several subsharan African countries, the process has been less sustained.

Second, another important consideration is the existence of a culture of consitutionalism. Where constitutions are regarded as the fundamental laws that must be respected by all-those in power as well as those outside of it-local government constitutionalism has had significant impact. Where this is not the case as in most of SSA and North Africa, such innovations might simply be regarded as window dressing. In the latter case, it would mean that the ground norms which the constitution represents have not been internalised by the people themselves) [13].

Finally, as we have argued earlier, the implementors of local government constitutional provisions-either as senior politicians and administrators-in power play a critical role in sustaining this innovation.

It is likely that as the pressures for deepening democratization gathers momentum across Africa, the issue of local government consitutitionalization would become an important one. There are rustlings already across the continent in the north, Eastern, western and southern parts. This paper suggests how that process can be analysed and supported.

\section{REFERENCES}

[1] World Bank, "World Development Report," Oxford University Press, Oxford, 2004.

[2] K. Millett, D. Olowu and R. Cameron, "Local Governance 
and Poverty Reduction in Africa,” Joint Africa Institute, Tunis, 2006.

[3] United Nations Development Program, "Supporting Capacities for Integrated Local Development," Practice Note, 21 November 2007.

[4] A. Shah, "Local Governance in Developing Countries," World Bank, Washington, 2006. doi:10.1596/978-0-8213-6565-6

[5] M. S. Grindle, "Good Enough Governance: Poverty Reduction and Reform in Developing Countries," John F. Kennedy School of Government, Havard University, Cambridge, 2002.

[6] D. Olowu, "Local Government Innovation in Nigeria and Brazil: A Comparative Discussion of Innovational Transfers and Intergovernmental Relations,” Public Administration and Development, Vol. 2, No. 4, 1982, pp. 345-357. doi:10.1002/pad.4230020406

[7] E. Ostrom, "Design Principles in Long Enduring Irrigation Institutions,” In: M. McGinnis, Ed., Polycentric Governance and Development, University of Michigan Press, Michigan, 1999, pp. 87-113.
[8] D. Olowu and J. Wunsch, "Local Governance in Africa: The Challenge of Democratic Decentralization,” Lynne Rienner Publishers, Boulder, 2004.

[9] N. Kersting, J. Caulfield, R. Nickson, D. Olowu and H. Wollmann, "Local Governance Reform in Global Perspective,” VS Verslag fur Socialwissenschaften, Berlin, 2009. doi:10.1007/978-3-531-91686-6

[10] N. Awortwi, “An Ubreakable Path? A Comparative Study Decentralization and Local Government Trajectories in Ghana and Uganda,” International Review of Administrative Sciences, Vol. 77, No. 2, 2011, pp. 347-378. doi:10.1177/0020852311399844

[11] J. Kathyola and O. Job, "Decentralization in Commonwealth Africa,” Commonwealth Secretariat, London, 2011.

[12] B. Olowu, R. Suberu, J. Erero and R. Soetan, “Comparative Assessment of Decentralization in Africa," Nigeria InCountry Assessment Report, USAID, Washington, 2010.

[13] H. W. Okoth-Ogendo, "The Quest for Constitutional Government,” In: G. Hyden, D. Olowu and H. A. Okoth-Ogendo, Eds., African Perspectives on Governance, Africa World Press, Inc., Trenton, 2000, pp. 33-60. 